\title{
Who Adjusts? Winners and Losers in the British Financial Policy Community in the 1980s
}

\author{
Oh Suk Yang* \\ (Seoul National University)
}

\section{$\langle$ Contents}

I . Introduction

II. Theoretical review and general configuration of the British financial policy community in the 1980 s
III. Different distributional outcomes and preferences in the financial policy community

IV. Conclusion

- Keywords: Big Bang, policy community, asymmetrical distribution, society-centric decision-making, winners and losers.

\section{【 ABSTRACT 】}

It will be only once research explores the question of "who, for practical purposes, drives the debate on European financial liberalization including capital decontrol,' and 'what goals and objectives are being pursued by decision makers,' that we can fully understand the actor-structure interactions in the evolutionary process of British financial reform. This article, therefore, explores how the amount of consideration allocated to different groups has affected the evolution of the debate centered on British financial liberalization.

* I would like to thank three discussants who have commented on the various drafts. Special thanks are due to Professor Sang Kee Min without whom this article might have remained incomplete. 


\section{I . Introduction}

General research on policies has paid little attention to policy shifts, including the demise of policies. Despite the lack of attention, policies are continually shifting. In the 1980s there was a policy shift expressed as freer capital movement and modernization in the global financial structure. In 1979 the US launched capital deregulation. The UK enforced capital decontrol in 1979 and Germany followed in 1981. These countries' initiatives were followed by capital decontrol in France in 1989. Also of note was the UK's implementation of the so-called 'Big Bang' sweeping financial reforms made in 1986. This series of events has aroused our curiosity in what stimulates policy shifts in the financial sector.

Generally speaking, a policy shift can be understood by examining it from 3 different perspectives. A policy shift can be thought of as: a) the restructuring of advocacy coalition centring on a specific policy,1) b) a challenge to the prevailing paradigm derived from an external crisis, ${ }^{2)}$ or c) a construct of a policy network in which the interests of government and interest groups are arbitrated.3) This article aims to explore the dynamic of the challenges to British financial policy in the 1980 s, by taking the view that they arose as constructs of a financial policy network. In reality, in any policy process some interests are privileged, whilst other interests are marginalized. In this sense, any study of British financial reform in the 1980s that is not accompanied by an exploration of the interest constellation involved in it would not be complete.

In this context, the guiding research question, i.e. the puzzle, in this article is to discover how 'who-gets-what is an asymmetric reflection of demand from sectors or actors in the British financial policy community in the 1980s.' The author's short-cut answer to this question is that the challenges to the financial policy were not pure outcomes of the demands of economic actors or market forces. Rather, this article contends that a policy shift was the hybrid outcome of a combination of demands made be economic and political actors. This argument is supported on the following bases: First, the British financial policy community had a different configuration to its balance of power and its construct of winners and losers than did the continental European countries. Second, the demands of the capital market, government, and political parties were not always consistent with each

1) See Paul A. Sabatier (ed.) Theories of the Policy Process (Oxford: Westview Press, 1999); Paul A. Sabatier, "An Advocacy Coalition Framework of Policy Change and the Role of Policy-Oriented Learning Therein," Policy Sciences, 2-3 (1988).

2) See Peter A. Hall, "Policy Paradigms, Social Learning, and the State: The Case of Economic Policymaking in Britain," Comparative Politics, (April, 1993).

3) See Hugh Heclo, "Issue Networks and the Executive Establishment," in Ahthony King(ed.), The New American Political System (Washington, D.C.: American Enterprise Institute, 1978), pp. 87-124; Maurice Wright, "Policy Community, Policy Network and Comparative Industrial Policies," Political Studies (1988); Grant Jordan, "Sub-Governments, Policy Communities and Networks: Refilling the Old Bottles," Journal of Theoretical Politics (1990); R.A.W. Rhodes, "Policy Networks: A British Perspective," Journal of Theoretical Politics (1990). 
other. The convergence of their demands required quite a long time.

The remainder of this article is divided into three sections. The second section traces a theoretical framework in order to verify the British financial policy community in the 1980s. The third section explores different distributional outcomes and preferences in the financial policy community. In the last section, this series of explorations leads us to the suggestion of some political implications and some research themes for future research.

\section{Theoretical review and general configuration of the British financial policy community in the 1980 s}

Until the early twenty-first century much of the literature on financial reform essentially fell into one of three strands. One is composed of often valuable and insightful descriptions by the structural perspective of how the internationalization of finance or increasing capital mobility has exercised a new and powerful influence on domestic policy-making.4) Although much has been written on capital movement, it has tended to be mainly based on structural determinism. Recently, this shortcoming has begun to be addressed in a series of works that explicitly seek to analyze the primacy of domestic politics in explaining regulatory reform.5) The third and growing strand composed primarily of scholars in international political economy (IPE) with a few economists, is concerned with how different the distributional consequences of financial liberalization and reform are for individual sectors and actors. $\left.{ }^{6}\right)$

As for the methodology which will be used, this article tries to reduce the significance

4) See Michael Webb, "International Economic Structures, Government Interests and International Coordination of Macroeconomic Adjustment Policies," International Organization, 45(1991); John

B. Goodman and Louis W. Pauly, "The Obsolescence of Capital Controls? Economic Management in an Age of Global Markets," in Jeffry A. Frieden and David A. Lake(eds.), International Political Economy: Perspectives on global power and wealth, third edition (London and New York: Routledge, 1995), pp. 299-317; Paulette Kurzer, Business and Banking: Political Change and Economic Integration in Western Europe (Ithaca: Cornell University Press, 1993).

5) See Geoff Garrett, "Capital Mobility, Trade and the Domestic Politics of Economic Policy," International Organization. 49(Fall, 1995); Michael Loriaux, France after Hegemony: International Change and Financial Reform (Ithaca and London: Cornell University Press, 1991); Henry Laurence, Money rules: the new politics of finance in Britain and Japan (Ithaca and London: Cornell University Press, 2001).

6) See Jeffry Frieden A., "Invested Interests: The Politics of National Economic Policies in a World of Global Finance," International Organization, 45(1991), pp. 425-51; Stephen Haggard and Sylvia Maxfield, "The Political Economy of Financial Internationalization in the Developing World," in Robert $O$. Keohane and Helen V. Milner(eds.), Internationalization and Domestic Politics (Cambridge: Cambridge University Press, 1996); Richard McIntyre, "The Political Economy of Intemational Financial Reforms: A Class Analysis," in Chronis Polychroniou(ed.), Perspectives and Issues in International Political Economy (Westport, Connecticut and London: PRAEGER, 1992), pp. 235-55. 
of the political dynamics within capital controls or decontrols to just the impact on 'who-gets-what' issue, i.e. the main theme of IPE. More practically, the abovementioned exploration will be consistent with the more classified specific-factor model suggested by Stephan M. Haggard and Sylvia Maxfield.7) This is because this model is amenable to covering the middle-range level and taking a society-centric perspective.8) A system-centric approach explains a policy as a function of the attributes or capabilities of a state relative to other nation-states. A state-centric approach understands a policy as highly constrained by domestic institutional relationships that have persisted over time, and also by the ability of state officials to realize their objectives in light of both international and domestic constraints. Unlike these approaches, the society-centric approach views a policy either as reflecting the preferences of the dominant group or class in society, or as resulting from the struggle for influence that takes place amongst various interest groups or political parties.9) As such, this approach is the function of domestic politics. Given that there has been exclusion of domestic dynamic in explaining a policy shift in the financial sector in the UK in the 1980s, more classified specific factor model enables us capture out the endogenous dynamic of financial reform in terms of state-society relationships.

In the meantime, we need also to identify who is who in 'who-gets-what.' It is because European countries have run different financial systems in which the main actors, those who set the agenda, shape the process of implementation, and determine outcomes, varies. This variation continues to diversify the policy community in Europe in which the interest presented by major actors varies substantially. A policy network or community is 'an arena for the mediation of the interests of government and interest groups'.10) In general, a number of actors are operating in the process of sectoral decision-making, and the asymmetric consideration of their conflicting interests is reflected in the policy configuration. This being the case, policy outcomes result from competition between different interests.

How can we describe the financial policy communities in the UK? "A 'financial policy community' can be said to incorporate all participants with direct interest - as depositors, investors, shareholders, stakeholders, lobbyists or regulators - in the evolution of the financial system." 11$)$ However, we need to remember that financial policy communities may even differ by issue. Nevertheless, assuming that all financial systems are tied into political structures and relationships, it is possible to illustrate the financial policy community in

7) See Haggard and Maxfield(1996), pp. 209-39.

8) R.A.W. Rhodes and David Marsh(eds.) Policy Networks in British Government (Oxford: Clarendon Press, 1992), pp. 3-4.

9) G. J. Ikenberry and M. Mastanduno, "Introduction: Approaches to Explaining American Foreign Economic Policy," International Organization, 42-1(1988), pp. 1-14.

10) J. Peterson, "Policy Networks and European Union Policy Making: A Reply to Kassim," West European Politics, 18-2(1995), p. 391.

11) Jonathan Story and Ingo Walter, Political economy of financial integration in Europe: The battle of the systems (Cambridge, Massachusetts: The MIT Press, 1997), pp. 136-37. 
the UK as depicted by <Figure1>.

$\langle$ Figure 1〉 National regulations and financial policy communities

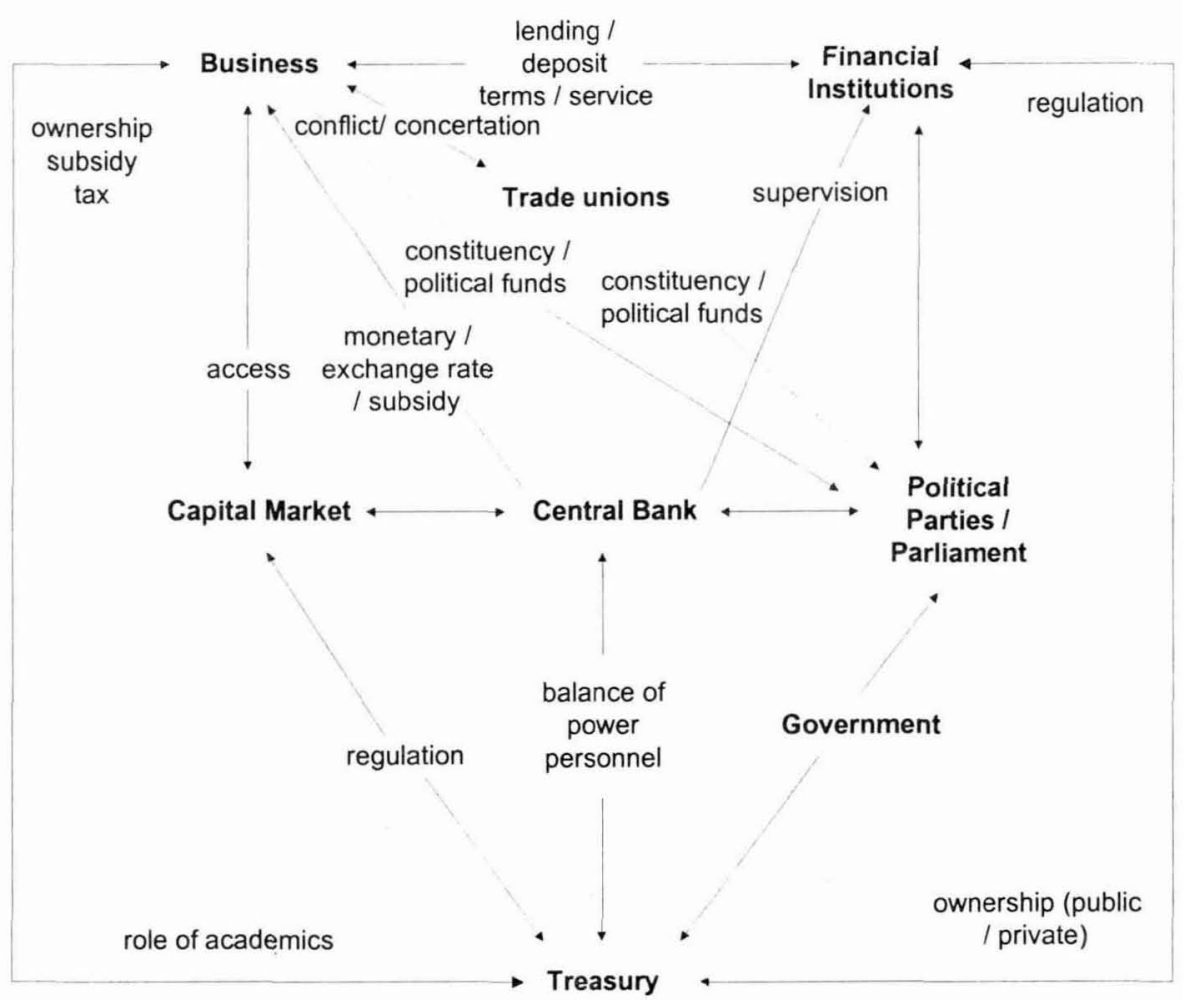

Source: This schematic is modified by the author based on a suggestion by Story and Walter (1997).

In the British financial policy community there have been business, financial institutions, and capital market, i.e. the City, acting as the major economic actors. On the other hand, central bank, treasury, trade unions and political parties have been representing political and social actors. Centring on their interactions, the next section in turn is organized to explore interest constellation operated in financial policy communities in the UK.

\section{Different distributional outcomes and preferences in the financial policy community}

\section{Treasury}

From a certain perspective, it is possible to observe that the treasuries of the EU member states had motives to take the initiative in liberalising and modernising the financial system due to their own need to raise necessary public funds. The fact that since 
the 1980 s, there has been a direct relation between the freeing of global finance and the worsening of public finances in the industrialised countries does nothing to weaken the veracity of this suggestion.

$\langle$ Table 1 > Variations in public finance of the EU countries*

\begin{tabular}{l|c|c|c}
\hline & $1961-73$ & $1987-94$ & 1995 \\
\hline \hline As \% of GDP (\%) & & & \\
Public deficit & -0.4 & -5.1 & -4.5 \\
Public debt interest & -0.7 & -5.0 & -5.5 \\
Public debt & 32.0 & 59.5 & 70.6 \\
Annual average (\%)* & & & 7.8 \\
Public debt interest & 2.2 & 8.4 & 10.3 \\
Growth of GDP & 10.2 & 6.7 & \\
\hline
\end{tabular}

Note: * Public finance in a broad scope including local and social public organisations.

Nine EU countries by 1973, whilst 15 EU countries since 1974 .

** Nominal interest.

Sources: European Commission, European Economy: REPORTS AND STUDIES (1990, 1995).

Since the early 1980 s the large industrialised countries have been suffering from the gradual worsening of public deficits. The average public deficit as \% of GDP for EU countries was $-0.4 \%$ in the 1960 s -1970 s and expanded to $-5.1 \%$ during 1987-94. As a result, the ratio of public debt has also increased to $59.5 \%$ of GDP during the period 1987-94 (see <Table 1>). As <Table 1> shows, we can see the most significant strains on public finance of the EU member states in the last couple of decades. As such, the priority in economic policies was to ensure sound public finance.

In this process, it is plausible that European treasuries could not depend solely on domestic investors. That is, they needed to attract international, particularly institutional, investors to buy public securities. How then could it possibly be done? In theory, the minimal, but not only, strategy for attracting international investors is to bring about an increase in market liquidity. To this end, treasuries from the first had to liberalise and modernise the financial system in order to enhance market liquidity.12) Ultimately, it was the increase in the ratio of foreign holding of domestic securities that made most European treasuries attain the goal of securing the required public funds.

As <Figure 2> shows, this was also the case in France and Germany. The German government transformed from having low (5.0) to high (25.9) dependency on the international market; so did the French government ( 0.0 to 31.8 ); by contrast, the British treasury did not show a significant shift (11.4 to 12.5). Such subtle differences in individual member states' dependency on the international market for raising the public funds may

12) As a part of it, most treasuries employed experts of public bonds, which owed a duty to establish standing bond markets. 
indicate that the French and German capital decontrols over the last couple of decades had been quite closely connected to governmental decisions or interests. By contrast, the British treasury had no direct incentive to modernise the financial system during the years 1979-1992.

$\langle$ Figure 2 $>$ Dependency on the international market for raising the public funds (the ratio of the foreign holding in the balance of the public debt, \%)

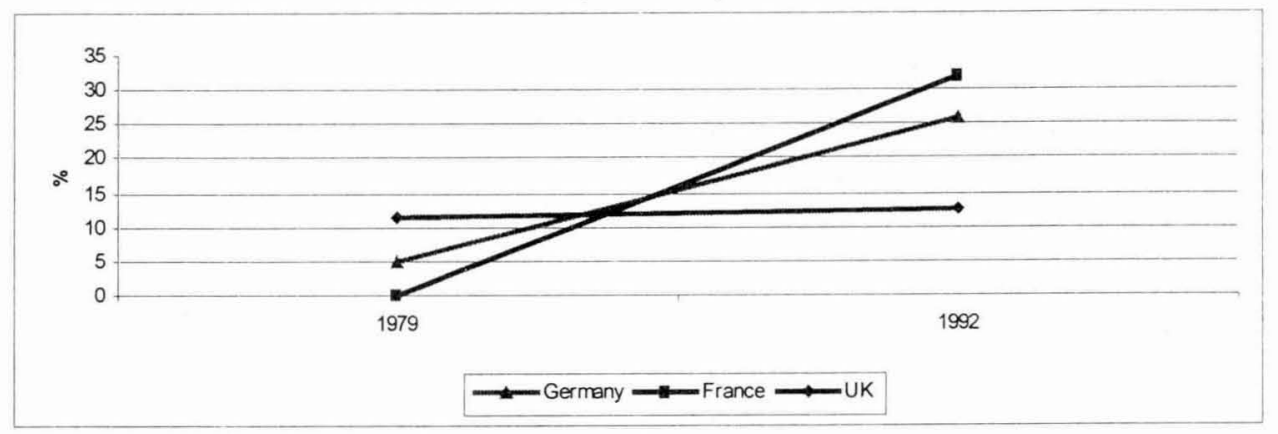

Note : British figures are for 1985 and 1991 respectively.

Source: IMF, International Capital Markets: Developments, Prospects, and Policy Issue (Washington, D. C.: IMF, 1995).

\section{Central banks}

The implications of financial innovation and liberalisation for the conduct of monetary policy are apparent. Financial liberalisation generates a considerable threat to the effectiveness of monetary policy that has been traditionally been set by national central banks in Europe, whilst it provided financial markets with great power. For instance, direct credit controls (credit rationing, liquidity constraints, etc.) traditionally employed by many European central banks became ineffective instruments of monetary control. Hence, monetary policy in recent years has moved towards the use of indirect policy instruments like open market operations and bank interest rates. ${ }^{13)}$

Another implication for monetary policy was that the financial revolution has changed the relationship between the intermediate target such as M314) and the final objectives such as inflation and nominal income. Taken together, the effectiveness of traditional monetary targeting has been called into question in a sense that monetary aggregates are affected by a wider range of domestic and international factors. ${ }^{15}$ )

The effectiveness of fiscal and exchange rate policies were also affected in association

13) Kenneth Dyson, et al. "Strapped to the mast: EC central bankers between global financial markets and regional integration," Journal of European Public Policy, 2-3(September, 1995).

14) Notes and coin in circulation + NBPS holdings of non-interest bearing sight bank deposits + NBPS holdings of bank time deposits + NBPS holdings of CDs with banks.

15) BIS, Annual Report (Basle: Bank of International Settlement, 1992, 1993). 
with capital mobility. Capital mobility generates a significant effect on national economies by inducing changes in exchange rates and, consequently, in trade conversion or price.16) European countries faced different exposures to the impact resulting from the pooling of authority on monetary policy in capital markets. Furthermore, it is also noteworthy that in Germany, the shift to monetarism came very early, whilst the UK changed its monetary policies somewhat later. On the other hand, France transferred to monetarism much later than either Germany or Britain. ${ }^{17)}$

Linked to the effect of monetary policy, the liberalists emphasise the aspect of 'confidence.' They argue that when a currency is attacked by others, there are two long-term equilibriums established in accordance with the central bank's response. One comes into being when the central bank is weak, in which case an attack by market forces results in a spontaneous devaluation. The other is that which occurs when the central bank is strong, in which case it replies to speculative attacks from market forces by implementing a tight-money policy causing the value of the currency to increase. ${ }^{18)}$

Suffice it to say that the European central banks were placed in a decidedly different position when they came to responding to financial globalisation, since they had significantly different levels of confidence.

〈Figure 3 Central bank independence in Europe (1989)

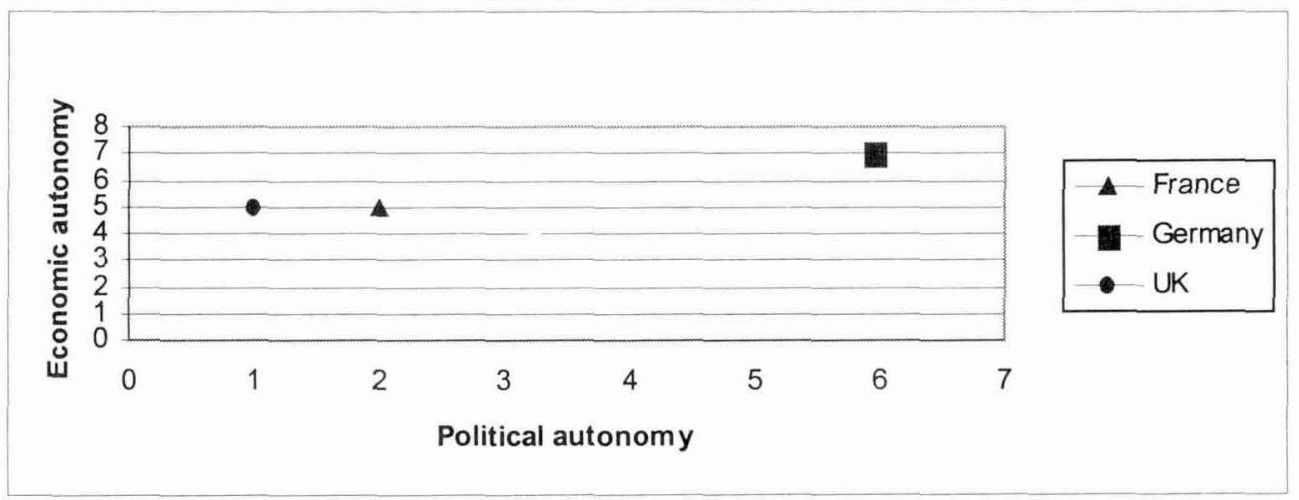

Source: Data from Vittorio Grilli, Donato Masciendaro and Guido Tabellini, "Political and Monetary Institutions and Public Financial Policies in the Industrial Countries," Economic Policy 13 (1991), pp. 341-92.

The independence of central banks in Europe varied significantly as depicted by $<$ Figure 3>. The German Bundesbank did rank first in terms of both political and economic autonomy, whilst the British central bank was low in political autonomy and high in economic autonomy in the 1980s. In conclusion, "it is the central bank's independence that

16) Paul R. Krugman and Maurice Obstfeld, International Economics: theory and policy (Reading, Massachusetts: Addison-Wesley Publishing Company, 2000).

17) Vivien A. Schmidt, The futures of European capitalism (Oxford: Oxford University Press, 2002).

18) François Chesnais, La mondialisation financière (SYROS, 1996). 
secures the market's confidence in it."19) In this context, independence was the policy project that not only enabled central bankers to negotiate the turbulence created by financial liberalization and by global financial markets but also, in the process, promised them increased authority and power.

\section{Banks}

The sudden advent of freer capital movement resulted in a series of changes in banks' interests. Above all, it caused instability in the banking system in the industrialised countries by preventing banks from offering the 'productive credit' that was necessary for raising investment funds and 'substitute credit' that was vital for recovering from economic difficulties. ${ }^{20}$ ) As a result, continental European banks have withered consistently.

〈Table 2〉 Long-term accounting indicators of banks' performance

\begin{tabular}{l|c|c|c|c|c|c}
\hline \multirow{2}{*}{ Countries } & \multicolumn{3}{|c|}{ Pre-tax profits } & \multicolumn{3}{c}{ Non-interest income } \\
\cline { 2 - 7 } & $1980-82$ & $1986-88$ & $1990-94$ & $1980-82$ & $1986-88$ & $1990-94$ \\
\cline { 2 - 7 } & \multicolumn{3}{|c|}{ As a percentage of assets } & \multicolumn{3}{|c}{ As a percentage of gross income } \\
\hline \hline Belgium & 0.4 & 0.4 & 0.3 & 15 & 22 & 26 \\
Finland & 0.5 & 0.5 & -1.6 & 49 & 58 & 53 \\
France & $\mathbf{0 . 4}$ & $\mathbf{0 . 4}$ & -0.1 & 16 & $\mathbf{1 7}$ & $\mathbf{4 6}$ \\
Germany & $\mathbf{0 . 5}$ & $\mathbf{0 . 7}$ & $\mathbf{0 . 5}$ & 29 & 30 & $\mathbf{2 9}$ \\
Italy & 0.7 & 1.0 & 0.8 & 26 & 29 & 26 \\
Netherlands & 0.3 & 0.7 & 0.6 & 25 & 26 & 30 \\
Norway & 0.6 & 0.0 & 0.2 & 27 & 30 & 29 \\
Spain & 0.7 & 1.1 & 0.6 & 18 & 20 & 27 \\
Sweden & 0.3 & 0.8 & 0.5 & 30 & 31 & 44 \\
UK & $\mathbf{1 . 1}$ & $\mathbf{1 . 0}$ & $\mathbf{0 . 7}$ & 29 & $\mathbf{3 7}$ & $\mathbf{4 3}$ \\
\hline
\end{tabular}

Source: BIS, Annual Report (Basle: Bank of International Settlement, 1997).

In France, bank credit has continued to decrease since 1992, and banks have been recording losses. As for the sum total of the funds flowing through the French economy, the rate of bank intermediation has decreased from $64.6 \%$ in 1985 to $22.6 \%$ in 1993 (see <Table 2>). Pre-tax profits diminished to -0.1 (as a percentage of assets) in 1990-94, whilst non-interest income increased up to 46 (as a percentage of gross income) in the same period. This was also the case in Germany, whilst German banks maintained a relatively stable level of non-interest income of about $30 \%$. Such poor performance by banks impacted their ability to raise funds in their national economies. However, the British banks maintained high pre-tax profits (as a percentage of assets) as to be performing strongly right through the recession. ${ }^{21)}$

19) Interview with a central banker from the Bank of England (January 2002).

20) Chesnais(1996). 


\section{Institutional investors}

With deep-seated structural transformations in world financial markets beginning in the 1970s, central banks faced challenges in defending their corporate interests. Above all, the opening of domestic financial markets in combination with frenetic product innovation such as derivatives (swaps, futures and options) encouraged new entrants into financial markets. New entrants consisted of insurance companies, mutual investment funds, pension funds and hedge funds. In turn, the important role of these new institutional investors was to undermine the traditional social and cultural cohesion between central banks and the narrow and exclusive domestic financial communities. As a result, it is possible to observe profound implications for the distribution of political power at the domestic level, opening up new cleavages and remaking political coalitions. ${ }^{22)}$

In the UK, the most striking trends in the post war history of the London Stock Exchange (LSE) were the declining importance of private investors and the concurrent increase in prominence of institutional investors. In 1963, individuals owned $54 \%$ of the UK shares, while institutional investors owned $30 \%$. By 1981, individual ownership had dropped to $28 \%$, and institutional ownership jumped to $58 \% .23$ )

〈Figure 4 Financial assets of institutional investors in the UK, France and Germany (in per cent of financial assets of domestic financial sectors)

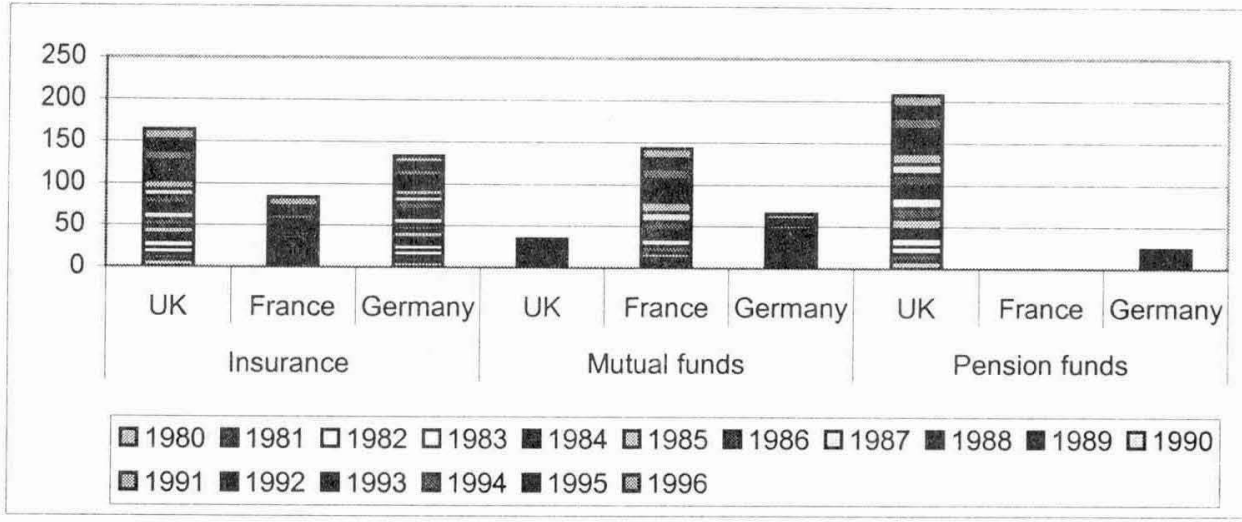

Notes: Insurance=life insurance; Mutual funds=Open-end investment companies; Pension funds=Autonomous pension funds

Sources: OECD, Institutional Investors: Statistical Yearbook (Paris: OECD, 1997, 1998).

The rise of institutional investors was a domestic factor that contributed to the Big Bang in the sense that they became increasingly frustrated with the old system ${ }^{24}$ ) and became

21) John Ross, Thatcher and Friends (London: Pluto, 1982); A. Gamble, The Free Economy and the Strong State: The Politics of Thatcherism (Durham: Duke University Press, 1988), p. 194.

22) Frieden(1991), pp. 425-51.

23) LSE, Stock Exchange Quarterly (London: LSE, June 1985), p. 17

24) Interview with official from Prudential Insurance, reading, June 1993; cited in Laurence(2001), p. 75. 
a force of resistance against it. The old system was appropriate with a large private client base, and in comparison with the US, private clients actually paid relatively low commission rates compared to institutional investors. However institutional investors did not need the protection of 'single capacity.' They dealt frequently and in large quantities, and preferred cheap dealing, which fixed commissions did not permit. Finally, in the 1970s, the LSE's biggest customers went so far as to set up their own exchange, ARIEL (Automated Real-Time Investment Ltd.), in an attempt to bypass the official LSE and its overpriced commissions. This prompted the LSE to reduce commission charges on large transactions, but the Bank of England refused to use it for their gilt25) business. Its presence, however, dramatically underscored the fact that big customers regarded the LSE's rules on fixed commissions as unacceptable.26)

\section{Big enterprises (industrial groups)}

Financial globalisation provides the industrial capitalists with two main benefits. One is the ability to secure necessary industrial capital at low rates of interest. Financial liberalisation results in the possibility for firms to get access to credit with more advantageous interest rates than the banks offer and to simultaneously secure short-term financial investment instruments of disposable liquidity. The other is to increase the mobility and liquidity of the financial resources which were concentrically held by industrial groups to a considerable extent. Financial liberalisation allows tremendous expansion in the financial activities of those groups to occur by increasing the possibility for firms to mobilise huge amounts of capital.27)

A comparative analysis by BIS of enterprises in industrialised countries indicates that a big increase in the value of financial assets held by non-financial enterprises has been recorded in France. Also, considerable increases have taken place in many other continental European countries. ${ }^{28)}$ The UK provides a distinct contrast to this feature: its ratio of tangible assets to GNP investment has increased. In addition, the rise in the value of shares on issue has been relatively large in the UK and France but relatively small in Germany. $<$ Figure 5> reveals the imprint of country differences in internal financing capacity of enterprises and in the use of various types of external finance. Large cross-country differences in ratios of total financial assets to GDP are strongly influenced by the value of enterprises holdings of equity claims in other firms. They are relatively high in France and, to a lesser extent, in Germany and the UK.

25) Fixed-interest UK government securities traded on the London Stock Exchange. They are called gilt-edged because it is certain that interest will be paid and that they will be redeemed on the due date.

26) Laurence(2001), pp. 75-76.

27) Chesnais(1996).

28) J. T. Kneeshaw, "A Survey of Non-financial Sector Balance Sheet in Industrialized Countries: Implications for the monetary policy transmission mechanism," Working Paper, no. 25, Bank for International Settlements (April, 1995). 
$\langle$ Figure 5> Non-financial enterprise sector: tangible asset and financial flow ratios

(a) Share issues as a \% of enterprise investment

(b) Ratio of tangible assets to GNP
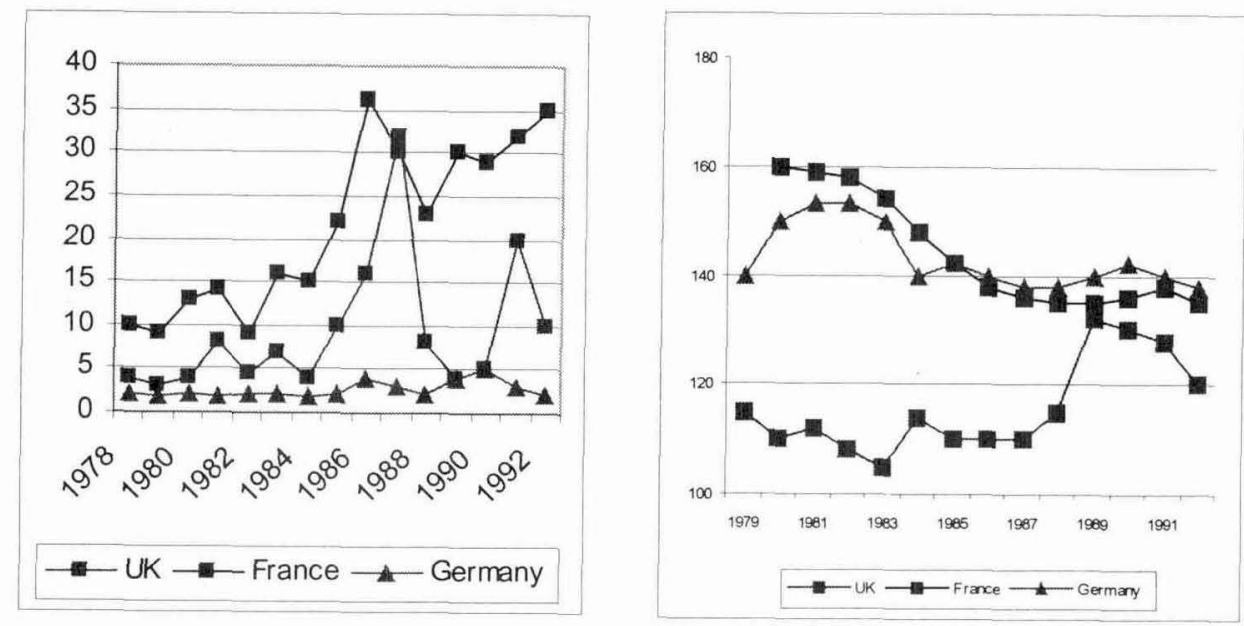

Source: Kneeshaw(1995), pp. 32, 36.

The holding of tangible assets by non-financial enterprises has on balance risen considerably over the last ten years in the UK but has fallen in relation to GDP in France and Germany. The ration of fixed reproducible capital has fallen in France since the early 1980s, changed little in Germany and risen in the UK since the late 1980s (see <Figure 5> (a)). Substantial rises in tangible assets in the UK in the late 1980s were partly reversed subsequent to enterprises curtailing investment as they sought to redress balance-sheet positions which had come to be viewed as overextended. This indicated that German and French firms that traditionally favoured the holding of tangible assets shifted on to preferring the holding financial assets.

\section{Small and Medium-sized Enterprises (SMEs)}

Looking at individual member states, as <Table 3> depicts, we can see that in France and Germany SMEs accounted for an average of more than 50 per cent of total turnover, whilst in the UK SMEs accounted for less than 45 per cent. This illustrates that the continental European countries were characterised by an SMEs-centric economic structure, whilst the UK was relatively large enterprises-centric.

The fortunes of SMEs' are closely associated with those of banks in the sense that SMEs are often excluded from direct access to international and capital markets and still rely on the national banking system. However, financial liberalisation has different implications for the bank-SMEs relationship in European countries. British commercial banks, despite their decline, could maintain their net interest income at a higher level than their counterparts in Germany and France could. This difference was originally derived from the different traditional debt structure of SMEs. 
〈Table 3 $>$ Turnover by employment size-class and sector of activity (\%)

\begin{tabular}{|c|c|c|c|c|}
\hline & 1988 & 1990 & 1992 & 1995 \\
\hline \multicolumn{5}{|l|}{$\underline{\mathrm{UK}}$} \\
\hline \multicolumn{5}{|l|}{ Industry } \\
\hline Large & 39.9 & & & 67.3 \\
\hline SMEs & 60.1 & 71.9 & 69.2 & 32.7 \\
\hline \multicolumn{5}{|c|}{ Financial intermediation } \\
\hline Large & 26.8 & $n /$ & $n$ & 61.0 \\
\hline SMEs & 73.2 & n/a & n/a & 39.0 \\
\hline \multicolumn{5}{|c|}{ All aggregates } \\
\hline Large & 39.6 & I & $n$ & 54.2 \\
\hline SMES & 60.4 & r/a & $1 / 1 / d$ & 45.8 \\
\hline \multicolumn{5}{|l|}{ France } \\
\hline \multicolumn{5}{|l|}{$\overline{\text { Industry }}$} \\
\hline Large & 55.6 & 54.8 & 64.6 & 63.2 \\
\hline SMEs & 44.4 & 45.2 & 35.4 & 36.8 \\
\hline \multicolumn{5}{|c|}{ Financial intermediation } \\
\hline Large & 11.3 & 12.3 & $\mathrm{n} / \mathrm{a}$ & 64.1 \\
\hline SMEs & 88.7 & 87.7 & & 35.9 \\
\hline \multicolumn{5}{|c|}{ All aggregates } \\
\hline Large & 36.7 & 42.7 & 46.6 & 43.7 \\
\hline SMEs & 63.3 & 57.3 & 53.4 & 56.3 \\
\hline \multicolumn{5}{|l|}{ Germany } \\
\hline \multicolumn{5}{|l|}{ Industry } \\
\hline Large & 70.3 & 69.7 & 76.0 & 67.4 \\
\hline SMEs & 29.7 & 30.3 & 24.0 & 32.6 \\
\hline \multicolumn{5}{|c|}{ Financial intermediation } \\
\hline Large & 2.8 & 3.0 & $\mathrm{n} / \mathrm{a}$ & 68.2 \\
\hline SMEs & 97.2 & 97.0 & & 31.8 \\
\hline \multicolumn{5}{|c|}{ All aggregates } \\
\hline Large & 49.8 & 47.2 & 46.2 & 47.6 \\
\hline SMES & 50.2 & 52.8 & 53.8 & 52.4 \\
\hline
\end{tabular}

Notes: Large (250+); SMEs (0-249); 'Data for industry in 1993; 'For industry, construction, trade and HoReCa.

Source: European Commission (various), Enterprises in Europe.

In the mid-1990s, the outcomes for European SMEs also varied considerably in relation to their debt structures. British SMEs (even large enterprises as well) have traditionally relied on internal funding and short term, particularly overdraft, finance. Such history could be also witnessed in 1992, as <Figure 6> depicts: 58 per cent of debt in British SMEs was overdraft finance in 1992, whilst long-term loans were 11 per cent. This is indicative of the fact that British SMEs are still have pursuing a path which allows them direct access to credit. 
$\langle$ Figure 6> Debt structure for SMEs (\% of total debt, 1992)

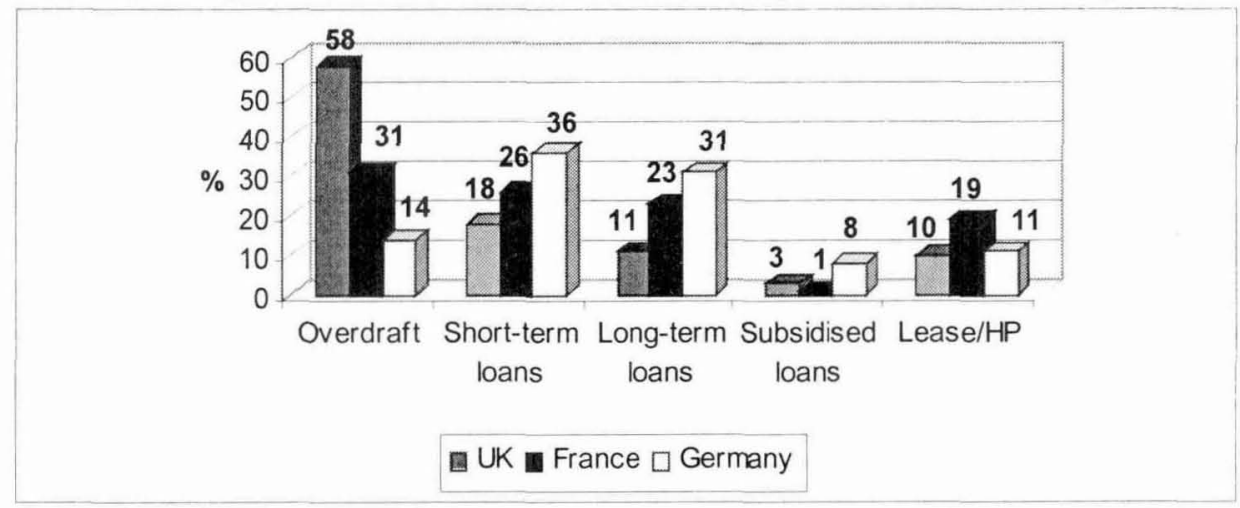

Note: short-term loans=Less than five years.

Source: Data from 3i/Cranfield European Enterprise Centre (1992).

On the other hand, although German companies during the 1980 s multiplied their number of business relations with many kinds of banks, they still maintained a stable and close relationship with one or two lead banks. ${ }^{29)}<$ Figure 6> highlights this feature: only 14 per cent of debt in German SMEs was overdraft, whilst long-term loans accounted for 31 per cent of debt. In France, by contrast, financial reforms have increased the number of ruptures between banks and SMEs and reinforced the companies' habit of 'shopping around' ${ }^{30)}$ Despite its being to a lesser extent than their counterparts in Britain, French SMEs continued to rely more on overdrafts and less on long-term lending than their German counterparts (see <Figure 6>).

\section{Labour (Trade unions)}

Although it is acknowledged that there are some variants of distributional outcomes by sector, this article will pay attention to the financial sector, in particular; the banking sector. Given the development of self-financing by corporations and the decrease in intermediation, French banks tried to overcome the crisis by reducing employment. Taken together, employment by French banks has consistently decreased since 1987, as shown by $<$ Figure $7>$ (a). In the final analysis, it was mainly the tremendous reduction in labour costs that enabled the balance sheets of financial businesses to rocket into the black. Such a strategy to survive was also utilised by German banks: the status quo of profit was accompanied by a decrease in employment (see <Figure $7>$ (b)).

By contrast, in the case of Britain we can witness more positive effects of Big Bang

29) U. Kirchhoff, Wachsender "Wettbewerb der kreditwirtschaft um mittelständische Unternehmen," Die Sparkasse, 8(1990), pp. 353-60.

30) Sigrid Quack and Swen Hildebrandt, "Bank Finance for Small and Medium-sized Enterprises," in Germany and France, in Glenn Morgan and David Knights(eds.), Regulation and Deregulation in European Financial Services (London: Macmillan, 1997), p. 122. 
on employment in the financial sector (Reid, 1990). According to a Bank of England survey, since Big Bang, London has retained its dominant status in the financial service sector. Such a status quo reflected in the increase of daily turnover in London in 1989 to more than twice that in 1986: $\$ 90$ billion in 1986, and $\$ 187$ billion in 1989. In terms of daily transactions, New York and Tokyo recorded \$129 billion and \$115 billion respectively. ${ }^{31)}$

$\langle$ Figure 7$\rangle$ Net profit and employment $(\%)$

(a) French banks

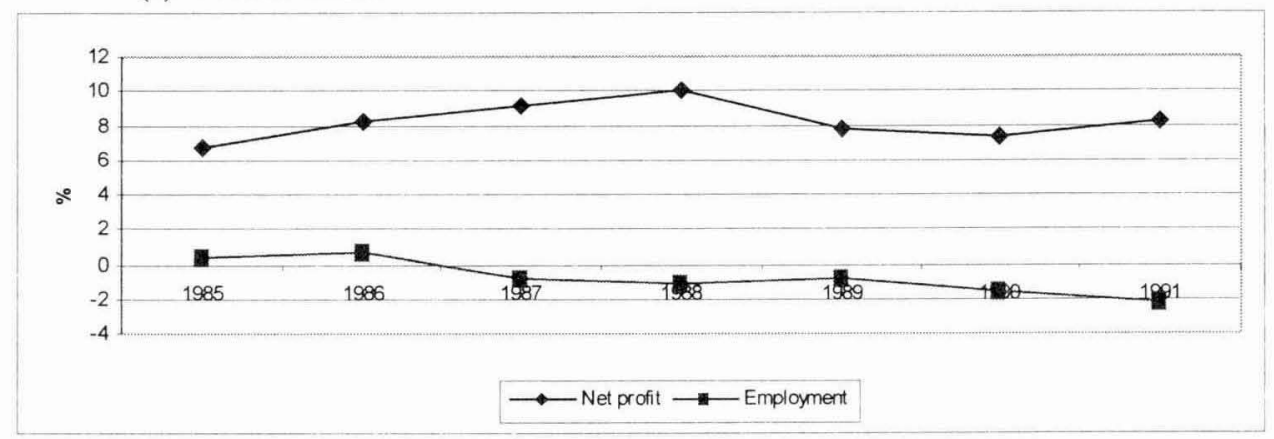

Source: INSEE, L'Économie Française: Rapport sur les Comptes de la Nation (Paris, 1994).

(b) German banks

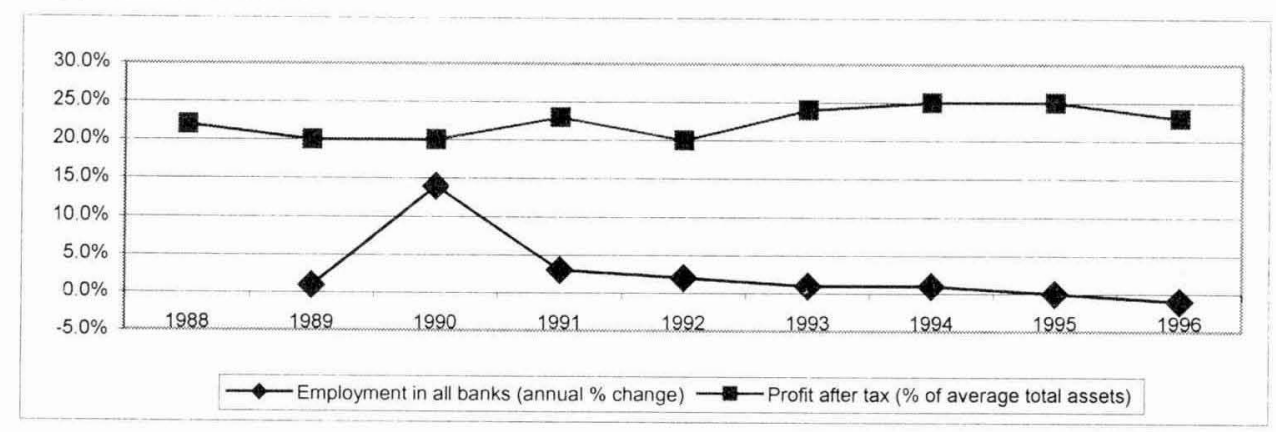

Source: OECD (various), Bank Profitability. Financial Statements of Banks.

The abovementioned positive effect of financial deregulation continued to increase employment in the fields of banking, finance, insurance, business service and leasing. In March 1989 employment in those fields was 2.63 million, which was equivalent to 22 per cent of the working population and a 52 per cent increase in numbers since 1981. As $<$ Table 4> depicts, the figure for Greater London was 784,000, which was equivalent to an increase of 30 per cent over eight years. In the post-Big Bang period, employment changes of +425 in 1987 and +962 in 1989 were recorded. Although we can witness some

31) Bank of England, Bank of England Quarterly Bulletin (London: Bank of England, 1987, 1989). 
job losses in the City, these statistics make it clear that British employment in the financial sector has grown to some extent until the end of the 1980s.32)

〈Table 4 Employment in the financial sector, the UK (numbers of employees in thousands)

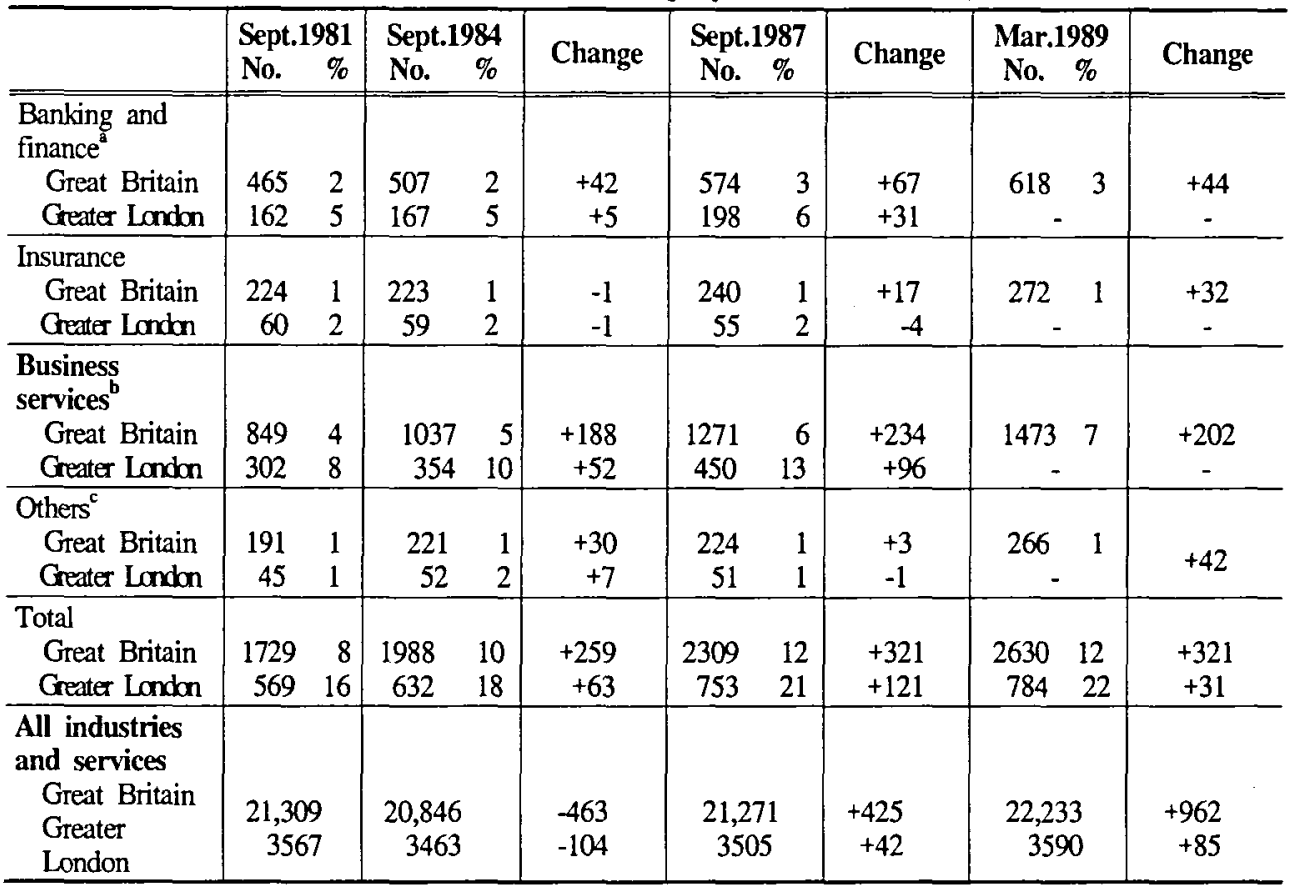

Notes: ${ }^{2}$ There may of course have been second-order employment gains in other sectors (such as the legal profession); ${ }^{6}$ Estimates by the London Chamber of Commerce suggest that employment by foreign banks and securities houses rose by 20,000 over 1984-87, before falling by 2000 in 1988 to stand at 53,000 ; ${ }^{c}$ Renting of movables and owning and dealing in real estate.

Sources: Bank of England, Bank of England Quarterly Bulletin (November 1989), p. 517; Reid(1990), p. 154.

\section{Capital Market}

Big Bang consisted of a series of market restructuring efforts such as the introduction of a new electronic trading system, the establishment of a new set of foreign exchange rules and an overhaul of the supervisory and regulatory structure. 33 ) This reform replaced the operating scope of brokers and dealers, accelerated the speed of trading and diffused the price quote and trading into the public. In addition, the LSE was restructured so as

32) Margaret Reid, "The City," in Peter Catterall(ed.), Contemporary Britain: An Annual Review 1990 (Oxford: Basil Blackwell, 1990), p. 155.

33) Ronald W. Masulis and Victor K. Ng, "Overnight and Daytime Stock-Retum Dynamics on the London Stock Exchange: The Impacts of "Big Bang" and the 1987 Stock-Market Crash," Journal of Business \& Economic Statistics, 13-4(October, 1995), p. 365. 
to reduce the volatility in stock markets and bring the asset value of stock profits up. ${ }^{34)}$ As such, for the LSE, these challenges were regarded as a fundamental revolution. ${ }^{35}$ )

During the 1970s the LSE has been confronted by sharp international competition. The LSE has linked to a number of foreign financial intermediaries that do not have memberships on the LSE. As such, it was natural for the LSE to put forth a dramatic effort in protecting the national financial centre by isolating foreigners from the national markets. However, subsequent to the decontrol of foreign exchange in October 1979, the LSE lost its monopolistic control on the national markets. As a result, it was before 1986 that the LSE began recognising that it needed to compete to maintain its status in international financial circles.36) The recognition of this led the LSE to feel that it was necessary to take a progressive step towards financial liberalization and reform by itself.

In fact, there had been pressures for reform since the beginning of the $1980 \mathrm{~s}$, when investigations by the Office of Fair Trading commenced into the fixed commissions levied by the Stock exchange members for share and bond transactions. There was also a more general realisation that the opportunities presented by a growing international securities market required a harmonisation with practices elsewhere, including an end to the 'single capacity, $\left.{ }^{37}\right)$ i.e. the division of brokers and jobbers ${ }^{38)}$ and a shift to computerised trading. In an agreement reached with the Board of Trade in 1983, the London Stock Exchange agreed to thoroughgoing reforms, including the ending of fixed commissions. As such, Big Bang in 1986 was not a sudden event, but rather a reform which went through a number of incremental stages, progressing in an accumulative way since the 1970s. ${ }^{39}$ )

However, endogenous movements towards financial liberalization and reform in the LSE were delayed by a political strategy of the British government. ${ }^{40)}$ As a result, political activities blocked the chance by which the dynamic of financial liberalization in the UK could be understood by the internal demand of LSE. The Conservative cabinet did not take

34) Masulis and $\mathrm{Ng}(1995)$, p. 365.

35) Oh Suk Yang, "The British Response To The Financial Liberalization In The 1980s And 1990s: West European Countries' Strategic Choices Looking For The Structural Power In International Political Economy," The Korean Journal of International Relations, 43-2(2003), pp. 403-28.

36) LSE, Stock Exchange Quarterly (London: LSE, 1980).

37) A term used to describe a situation where a market maker on a stock exchange deals only with other professionals and not with the investors (Graham Bannock and William Manser, International Dictionary of Finance (London: Penguin, 1999), p. 247). The opposite term is 'dual capacity': the situation where a market maker can buy or sell shares to and from members of the public or other members of the stock exchange without the need for a broker. The market maker acts as both jobber and broker (Bannock and Manser(1999), p. 81).

38) Dealers in securities who will buy and sell specific securities at all times, a market maker. Prior to the Big Bang, jobbers were one of two distinct classes of members of the London Stock Exchange who were permitted to deal only with brokers and not with the general public. The term is now obsolete (Bannock and Manser(1999), p. 149).

39) Yang(2003).

40) See next section for details. 
any final decision on what the LSE asked from the British govemment until the general election proved a victory for the Conservative party. It was, in fact, in 1983 that the British Conservative regime responded to the demands of the LSE, when the Tories won the general election. As such, during the years 1979-83 it was impossible to observe any signals of government-driven agendas towards financial liberalization and reform.

\section{Political Parties}

1982-87 was the time when the Thatcher regime was restoring its popularity in a dramatic way. During May 1982, after the Falklands war, to March 1985, the end of the miners strike, the popularity of the British Conservative regime maintained at over $40 \%$. Such an increase in the government's popularity was supported by the well-received reactions to the British Conservative regime's confrontation of the crisis in the Falklands in April 1982, the Argentinians' seizure of the Falkland Islands. This event exerted a strong influence on restoring the credibility of the British Conservative regime. The Falklands war lifted the authorities of the British government and provided the Conservative party with political fortunes. ${ }^{41)}$ Thereafter, the Conservatives were generally in ascendancy until the celebration of a resounding victory in 1987.

Given the results of general elections in 1979 and 1983, it was impossible to discern any big difference between them. Probably, economic prosperity, the segmentation of the opposition, and the geographical concentration of the backers for the Conservatives bolstered the advantageous position of the party. By contrast, Neil Kinnock, a new leader of the Labour party, failed to recover from the Labour party's political recession despite his tremendous election campaign. On the other hand, in Alliance, Roy Jenkins, the leader of Social Democratic Party (SDP) in 1983, generated a reasonable victory in his early leadership, winning $22 \sim 26 \%$, coming third in the general election. However, he failed to restore the popularity of SDP beyond this event. Finally, as the election came up, SDP was stuck between the two big parties.

In the early 1980s, Thatcherite ideas dominated the parties and two decisive election victories and the improving economy made it impossible to doubt Thatcher's leadership, whilst many politicians wondered about the rough relationship between parliamentary parties and Thatcherism. ${ }^{42)}$ In the meantime, there is also no doubt that there was a very determined Conservative government drive behind the new turn in policy and probably a matching unwillingness to be deterred by any obstacles to it. ${ }^{43)}$ As the Office of Fair Trading (OFT) referred 173 of the LSE's rules to the Restrictive Practices Court (RPC), the LSE had appealed unsuccessfully to the Labour and Conservative ministers, from 1976 until 1983. However, shortly after the 1983 Conservative election victory, the Thatcher

41) Anthony Barnett, "Iron Britannia," New Left Review, 134(1982), pp. 5-96.

42) Gamble(1988), pp. 118-120.

43) Margaret Reid, All-Change in the City: The Revolution in Britains Financial Sector (London: Macmillan, 1988). 
regime agreed to drop the OFT case, and in return, the LSE agreed to abandon fixed commissions and allow outsiders into the council.44)

As the general election was drawing near, the Conservative regime preferred to avoid the criticism that the incumbent cabinet under Thatcher's leadership was responding to the demands of the LSE so as to be inordinately amicable to the City, one of its most passionate backers. ${ }^{45)}$ Furthermore, Thatcher was trying to strengthen governmental control over enterprises by utilising the logic of a 'people's party' for the Conservatives, placing a priority on people's interests rather than those of enterprises, whilst it marched to the tune of anti-trade union programmes. As such, the Conservative Thatcher regime did cast the attributes of a strong regulatory state on the City, and the Thatcher regime enjoyed its crushing victory in the general election in June 1983. After the 1983 Conservative election victory, Thatcher regime was looking after its City friends and in retum, the new Conservative administration was successfully encouraging competition on the Exchange. In this process, Thatcher regime was certainly playing the role of leader rather than follower in the events.

\section{Conclusion}

From the series of explorations above, it is possible to witness that in Britain there was an asymmetric reflection of demands from sectors or actors; that there had been some heavy losers under Thatcherite ideas, such as SMEs, whilst a significant bloc of capital had benefited;46) and that in Britain Big Bang generated more positive effects on employment in the financial sector, which provided a distinct contrast to German and French cases. In addition, it can be said that there was no resistance that was strong enough to bring about a converse policy signal in Britain. Decision makers did not confront any significant resistance from other actors in embodying their own causal knowledge in capital decontrol. This was because the significant actor's demands were consistent with the policy orientation of the state. In particular, the interests of big enterprises \& MNCs, banks and central banks were in favour of capital decontrols, and to them there was given a formal channel through which their interests could be reflected in policy-making.

In British economic life, in which the role of banks was not important, it was big enterprises and MNCs that played the role of agenda-setters. In the late 1970s and the early 1980 s, when trade barriers were being strengthened by protectionism, big enterprises and MNCs pursued international production as an 'exit' option. According to this strategy, big enterprises and MNCs purchased numerous financial assets and pursued internationalisation.

44) Laurence(2001).

45) Ranald C. Michie, The London Stock Exchange: A History (Oxford: Oxford University Press, 1999).

46) Ross(1982); Gamble(1988), p. 194. 
In this situation, capital decontrol was necessary for the implementation of their strategies. The opportunity to reflect big enterprises and MNC's interests in policy-making increased as firms status rose in the eyes of the government.

By contrast, there was no channel through which the SMEs could transmit their rejection of capital decontrol to the policy-makers. In addition, the SMEs could not form a significant 'advocacy coalition' against early capital decontrol with banks because of their lack of close links with one another. This is, however, not to say that banks did not exert any influence on the process of executing capital decontrol. Compared to their counterparts in other European countries, the British banks performed strongly right through the recession,47) despite the dramatic shift in the early 1980s. As such, it was easier for the British banks to adjust to the new financial environment including capital decontrols.

As such, in Britain the site from which policy signals emanated had indeed been moved from the government to the economic sectors such as big enterprises and banks, i.e. the City. However, economic actors' demands could not be embodied in a policy shift without a positive consensus of the political actors. Therefore, it is possible to witness that there was an interaction structure in the financial policy community in the UK in the 1980 s.

On the other hand, this study cannot tell us the full story of the capital decontrols in the UK in the 1980s. This is because there are many factors not covered in this article. First, we need to understand the British variance in responding to capital decontrol from the viewpoint of international politics. This is because, unlike timing, in explaining the speed of a policy shift we can see the role of causality played by four structural powersproduction, security, research and development (R\&D), and finance-within the international political and economic system. ${ }^{48)}$ Second, the timing of a policy shift toward free capital movement had a combination of structural attributes, and reflected an asymmetry in interest allocation and decision makers causal knowledge. In the processes of capital decontrol in the UK, these factors generated no existence of sole causality or correlation. As such, whether or not structural attributes paved the way for the earlier penetration process of foreign capital to the domestic economic life was not pre-determined.

Without being accompanied by these explorations, this study cannot be perfect in providing readers with a full understanding of capital decontrols in the UK in the 1980s. The author hopes this article will provide an impetus for other future researches in which those missing factors are considered.

47) $\operatorname{Ross}(1982)$.

48) Susan Strange, STATES AND MARKETS $2^{\text {nd }}$ ed. (London and New York: Pinter, 1988, 1994). 


\section{References}

\section{Primary Sources}

Interview with Peter Sinclair - a central banker from the Bank of England (January 2002).

\section{Secondary Sources}

3i/Cranfield European Enterprise Centre, 1992.

Bank of England, Bank of England Quarterly Bulletin, (London: Bank of England), 1987, 1989.

Bannock, Graham and William Manser, International Dictionary of Finance, (London: Penguin), 1999.

Barnett, Anthony, "Iron Britannia," New Left Review, 134 (1982).

BIS, Annual Report, (Basle: Bank of International Settlement), 1992, 1993, 1997.

Chesnais, François, La mondialisation financière, (Paris: SYROS), 1996.

Dyson, Kenneth et al., "Strapped to the mast: EC central bankers between global financial markets and regional integration," Journal of European Public Policy, 2-3 (September, 1995).

European Commission (various), Enterprises in Europe.

European Commission, European Economy: REPORTS AND STUDIES, (Brussels: European Commission), 1990, 1995.

Frieden, Jeffry A., "Invested Interests: The Politics of National Economic Policies in a World of Global Finance," International Organization, 45 (1991).

Gamble, A., The Free Economy and the Strong State: The Politics of Thatcherism, (Durham: Duke University Press), 1988.

Garrett, Geoff, "Capital Mobility, Trade and the Domestic Politics of Economic Policy," International Organization, 49 (Fall, 1995)

Goodman, John B. and Louis W. Pauly, "The Obsolescence of Capital Controls? Economic Management in an Age of Global Markets," in Jeffry A. Frieden and David A. Lake(eds.), International Political Economy: Perspectives on global power and wealth, third edition (London and New York: Routledge), 1995.

Grilli, Vittorio, Donato Masciendaro and Guido Tabellini, "Political and Monetary Institutions and Public Financial Policies in the Industrial Countries," Economic Policy, 13 (1991).

Haggard, Stephen and Sylvia Maxfield, "The Political Economy of Financial Internationalization in the Developing World," in Robert O. Keohane and Helen V. Milner(eds.), Internationalization and Domestic Politics, (Cambridge: Cambridge University Press), 1996.

Hall, Peter A., "Policy Paradigms, Social Learning, and the State: The Case of Economic Policymaking in Britain," Comparative Politics, (April, 1993).

Heclo, Hugh, "Issue Networks and the Executive Establishment," in Ahthony King(ed.), 
The New American Political System, (Washington, D.C.: American Enterprise Institute), 1978.

Ikenberry, G. J. and M. Mastanduno, "Introduction: Approaches to Explaining American Foreign Economic Policy," International Organization, 42-1 (1988).

IMF, International Capital Markets: Developments, Prospects, and Policy Issue, (Washington, D. C.: IMF), 1995.

INSEE, L'Économie Française: Rapport sur les Comptes de la Nation, (Paris: INSEE), 1994.

Jordan, Grant, "Sub-Governments, Policy Communities and Networks: Refilling the Old Bottles," Journal of Theoretical Politics, (1990).

Kirchhoff, U., "Wachsender Wettbewerb der kreditwirtschaft um mittelständische Unternehmen," Die Sparkasse, 8 (1990).

Kneeshaw, J. T., "A Survey of Non-financial Sector Balance Sheet in Industrialized Countries: Implications for the monetary policy transmission mechanism," Working Paper, no. 25, Bank for International Settlements, (April, 1995).

Krugman, Paul R. and Maurice Obstfeld, International Economics: theory and policy, (Reading, Massachusetts: Addison-Wesley Publishing Company), 2000.

Kurzer, Paulette, Business and Banking: Political Change and Economic Integration in Western Europe (Ithaca: Cornell University Press), 1993.

Laurence, Henry, Money rules: the new politics of finance in Britain and Japan, (Ithaca and London: Cornell University Press), 2001.

Loriaux, Michael, France after Hegemony: International Change and Financial Reform (Ithaca and London: Cornell University Press), 1991.

LSE, Stock Exchange Quarterly, (London: LSE), 1980, 1985.

Margaret, Reid, All-Change in the City: The Revolution in Britains Financial Sector, (London: Macmillan), 1988.

Masulis, Ronald W. and Victor K. Ng, "Overnight and Daytime Stock-Return Dynamics on the London Stock Exchange: The Impacts of "Big Bang" and the 1987 Stock-Market Crash," Journal of Business \& Economic Statistics, 13-4 (October, 1995).

McIntyre, Richard "The Political Economy of International Financial Reforms: A Class Analysis," in Chronis Polychroniou(ed.), Perspectives and Issues in International Political Economy (Westport, Connecticut and London: PRAEGER), 1992.

Michie, Ranald C., The London Stock Exchange: A History, (Oxford: Oxford University Press), 1999.

OECD (various), Bank Profitability. Financial Statements of Banks.

OECD, Institutional Investors: Statistical Yearbook, (Paris: OECD), 1997, 1998.

Peterson, J., "Policy Networks and European Union Policy Making: A Reply to Kassim" West European Politics, 18-2 (1995).

Quack, Sigrid and Swen Hildebrandt, "Bank Finance for Small and Medium-sized Enterprises in Germany and France," in Glenn Morgan and David Knights(eds.), 
Regulation and Deregulation in European Financial Services, (London: Macmillan), 1997.

Reid, Margaret, "The City," in Peter Catterall(ed.), Contemporary Britain: An Annual Review 1990, (Oxford: Basil Blackwell), 1990.

Rhodes, R.A.W. and David Marsh, (eds.), Policy Networks in British Government, (Oxford: Clarendon Press), 1992.

Rhodes, R.A.W., "Policy Networks: A British Perspective," Journal of Theoretical Politics, (1990).

Ross, John, Thatcher and Friends, (London: Pluto), 1982

Sabatier, Paul A. (ed.), Theories of the Policy Process, (Oxford: Westview Press), 1999.

Sabatier, Paul A., "An Advocacy Coalition Framework of Policy Change and the Role of Policy-Oriented Learning Therein," Policy Sciences, 2-3 (1988).

Schmidt, Vivien A., The futures of European capitalism, (Oxford: Oxford University Press), 2002.

Story, Jonathan and Ingo Walter, Political economy of financial integration in Europe: The battle of the systems, (Cambridge, Massachusetts: The MIT Press), 1997.

Strange, Susan, STATES AND MARKETS $2^{\text {nd }}$ ed., (London and New York: Pinter), 1988, 1994.

Webb, Michael, "International Economic Structures, Government Interests and International Coordination of Macroeconomic Adjustment Policies," International Organization, 45 (1991)

Wright, Maurice, "Policy Community, Policy Network and Comparative Industrial Policies," Political Studies (1988). 